\title{
UPAYA MENINGKATKAN AKTIVITAS BELAJAR SISWA DENGAN MENERAPKAN MODEL PEMBELAJARAN PROBLEM POSING TIPE PRE SOLUTION POSING DI SMP NEGERI 15 KOTA BENGKULU
}

\author{
${ }^{1}$ Mely Agustin, ${ }^{2}$ Nurul Astuty Yensy B., ${ }^{3}$ Rusdi \\ 1,2,3 Program Studi Pendidikan Matematika JPMIPA FKIP Universitas Bengkulu \\ Email : ${ }^{1}$ melyagustin123@gmail.com, ${ }^{2}$ nurulastutyyensy@yahoo.com , ${ }^{3}$ rusdipendmat12@gmail.com
}

\begin{abstract}
Abstrak
Penelitian ini bertujuan untuk mengetahui cara menerapkan model pembelajaran Problem Posing Tipe Pre Solution Posing dalam pembelajaran sehingga terjadi peningkatan aktivitas belajar siswa. Jenis penelitian yang dilaksanakan adalah Penelitian Tindakan Kelas (PTK). Subjek penelitian ini adalah 32 siswa kelas VIII B SMP Negeri 15 Kota Bengkulu tahun ajaran 2016/2017. Instrumen yang digunakan adalah lembar observasi aktivitas belajar siswa. Indikator keberhasilan tindakan dalam penelitian ini adalah hasil lembar observasi aktivitas belajar siswa secara umum mencapai kriteria Aktif (pada lembar observasi aktivitas belajar memenuhi interval $23<x \leq 30$ ). Hasil penelitian menunjukkan terjadi peningkatan aktivitas belajar siswa yang dilakukan dengan cara memberi motivasi kepada siswa untuk aktif dalam kegiatan pembelajaran dan presentasi dan memberi tambahan nilai untuk siswa yang berani mengeluarkan pendapat didepan kelas dan yang aktif bertanya saat presentasi berlangsung. Peningkatan aktivitas siswa dapat dilihat dari rata-rata skor pada lembar observasi aktivitas belajar siswa siklus I sampai siklus III secara berturut-turut: 15,17 (kriteria kurang aktif); 20,84 (kriteria cukup aktif); 25,83 (kriteria aktif).
\end{abstract}

Kata kunci: problem posing tipe pre solution posing; aktivitas belajar.

\begin{abstract}
This research aims to found out how to applyed Problem Posing Model Pre solution Posing Type in learning so that there were increased students learning activity. The design of this research was Classroom Action Research (PTK). The subjects of this research were students of class VIII B Junior High school 15 Bengkulu City in academic years 2016/2017. The instrument of this research was observated sheet of student learning activity. The indicators of the success of the actions in this research were student learning activities in active criteria (in result students learning activitiy interval contain $23<x \leq 30$ ). The result of the research saw that there was an increased of students' learning activity by giving motivation to the students to be active in the learning and presentation activities and gave additional value for the students who dare to express their opinions in front of the class and actively inquire during the presentation. Increased student activity can be seen from the average score on the observation sheets of student learning activities cycle I to cycle III in a row: 15,17 (criteria less active); 20.84 (fairly active criteria); 25.83 (active criteria).
\end{abstract}

Keywords: problem posing model pre solution posing type; learning activity.

\section{PENDAHULUAN}

Matematika sebagai salah satu mata pelajaran yang berfungsi mengembangkan kemampuan menghitung, mengukur, dan menggunakan rumus matematika dalam kehidupan sehari-hari. Oleh karena itu, setiap generasi manusia menyadari pentingnya mempelajari matematika. Matematika diajarkan kepada siswa sejak sekolah dasar hingga perguruan tinggi yang memuat pengetahuan dasar dan tekhnologi. Pelajaran matematika di sekolah tidak hanya menekankan pada pemberian materi dari guru kepada siswa, siswa belajar bukan menghafal dan bukan pula mengingat. Menurut Sardiman (2011:97) dalam kegiatan belajar siswa harus aktif berbuat. Siswa di tuntut untuk lebih aktif dalam menggali pengetahuan-nya sendiri sedangkan guru sebagai pemimpin dan sebagai fasilitator belajar yakni mengatur dan mengorganisasi 
siswa sehingga proses pembelajaran dapat berjalan dengan baik.

Berdasarkan hasil observasi dikelas VIII SMP Negeri 15 Kota Bengkulu didapatkan informasi bahwa aktivitas belajar siswa dalam mengikuti pelajaran dikelas masih rendah. Hal ini dikarenakan pembelajaran yang masih didominasi oleh guru, Interaksi antara guru dengan siswa yang belum maksimal menyebabkan kurang adanya partisipasi siswa dalam proses pembelajaran. Kemudian ketika guru menjelaskan masih banyak siswa yang acuh tak acuh dan tidak memperdulikan.

Selain itu, siswa lebih cenderung diam dan malu untuk bertanya secara langsung kepada guru tentang apa yang tidak mereka pahami, serta siswa terbiasa hanya menyelesaikan soal yang diberikan guru atau soal yang ada pada buku cetak dan belum terlatih untuk membuat soal secara mandiri berdasarkan informasi yang diberikan. Untuk itu perlu adanya penerapan model pembelajaran yang membuat siswa lebih aktif dalam proses pembelajaran.

Suryosubroto (2009:203) mengemuka -kan bahwa salah satu model pembelajaran yang cocok untuk dapat meningkatkan aktivitas belajar siswa adalah dengan menerapkan model pembelajaran Problem Posing tipe Pre Solution Posing. Model pembelajaran ini dapat digunakan untuk memancing siswa menemukan pengetahuan yang didapat melalui upaya mencari hubungan-hubungan dalam informasi yang dipelajari, sehingga dapat meningkatkan aktivitas belajar siswa dikelas. Model pembelajaran Problem Posing Tipe Pre Solution Posing adalah suatu model pembelajaran yang melatih siswa agar mampu membuat soal sekaligus jawaban berdasarkan informasi atau situasi yang diberikan oleh guru (Throbroni, 2015:288).

Model pembelajaran Problem Posing memiliki tiga tipe pembelajaran yait tipe pre solution posing, within solution posing, dan post solution posing. Tipe pre solution posing ini dipilih karena dengan membuat soal secara mandiri, siswa perlu membaca informasi yang diberikan dan mengomunikasikan pertanyaan secara verbal maupun tertulis. Menulis pertanyaan dari informasi yang ada dapat menyebabkan ingatan siswa jauh lebih baik.
Kemudian, dalam pembuatan soal siswa diberi kesempatan menyelidiki dan menganalisis informasi untuk dijadikan soal. Kegiatan menyelidiki tersebut bagi siswa menentukan apa yang dipelajari, kemampuan menerapkan penerapan dan perilaku selama kegiatan belajar. Hal tersebut menunjukkan kegiatan pembuatan soal dapat memantapkan kemampuan belajar siswa.

Dalam menerapkan model pembelajaran problem posing tipe pre solution posing ini siswa dilatih untuk membuat soal secara mandiri dan mempresentasikan soal buatannya didepan kelas. Kegiatan ini dapat mengarahkan siswa untuk aktif bertanya tentang hal-hal yang belum dipahami dalam membuat soal dan melatih siswa untuk berani mengeluarkan pendapat atas apa yang telah dipresentasikan oleh temannya.

Adapun langkah-langkah pelaksanaan model pembelajaran Problem Posing tipe Pre Solution Posing yang digunakan oleh peneliti berdasarkan modifikasi pendapat dari Shoimin (2016:134) dan Panuntun (2016:128) yaitu :

1. Guru menjelaskan materi pelajaran kepada siswa

2. Guru memberikan beberapa contoh soal terkait materi yang sedang dipelajari

3. Guru membagikan Lembar Petunjuk Pembuatan Soal (LPPS) kepada siswa

4. Guru meminta masing-masing siswa untuk membuat soal berdasarkan informasi yang tertera di dalam LPPS lalu meminta siswa membuat penyelesaian dari soal yang telah dibuatnya

5. Guru meminta siswa untuk mengumpulkan LPPS beserta soal dan jawaban yang telah dibuatnya

6. Secara acak guru meminta/menunjuk beberapa siswa untuk mempresentasikan soal dan jawaban yang telah dibuatnya di depan kelas.

Berdasarkan langkah-langkah diatas terlihat bahwa dalam proses pembelajaran dengan menggunakan model pembelajaran Problem Posing tipe Pre Solution Posing siswa dituntut aktif dan dilatih untuk terbiasa membuat soal dan jawaban berdasarkan informasi yang diberikan. Sebagai suatu model pembelajaran, Problem Posing tipe Pre 
Solution Posing memiliki beberapa kelebihan, diantaranya yaitu : (1) mendidik siswa berpikir kritis dan kreatif; (2) siswa aktif dalam pembelajaran; (3) siswa tidak terpaku pada soal yang diberikan guru; (4) siswa terlatih membuat pertanyaan dan jawaban berdasarkan informasi yang diberikan, (5) meningkatkan rasa ingin tahu siswa; (6) meningkatkan wawasan siswa terhadap materi yang diajarkan dari soal-soal yang bervariasi; (7) menimbulkan rasa percaya diri (Modifikasi Throbroni, 2015 : 287). Penerapan model pembelajaran problem posing tipe pre solution posing ini diharapkan dapat memotivasi siswa untuk belajar sehingga dapat meningkatkan aktivitas belajar siswa di kelas.

Aktivitas belajar adalah aktivitas yang bersifat fisik maupun mental, dimana dalam kegiatan belajar kedua aktivitas tersebut saling berkaitan sehingga akan mengahasilkan aktivitas belajar yang optimal (Sardiman, 2011:100). Dalam belajar sangat diperlukan adanya aktivitas. Pada prinsipnya belajar adalah berbuat, dimana dalam hal ini siswa melakukan kegiatan untuk mengubah tingkah laku. Sekolah adalah salah satu pusat kegiatan belajar. Aktivitas disekolah cukup kompleks dan bervariasi. Banyak jenis aktivitas yang dapat dilakukan siswa di sekolah. Aktivitas siswa tidak cukup hanya mencatat dan mendengarkan. Paul B. Diedrich dalam Sardiman (2011:101) membuat suatu daftar yang berisi 177 macam kegiatan siswa yang antara lain dapat digolongkan sebagai berikut :

1. Visual activities, yang termasuk didalamnya misalnya : membaca, memperhatikan gambar demonstrasi, percobaan, pekerjaan orang lain.

2. Oral activities, seperti : menyatakan, merumuskan, bertanya, memberi saran, mengeluarkan pendapat, mengadakan wawancara, diskusi, interupsi.

3. Listening activities, sebagai contoh mendengarkan : uraian, percakapan, diskusi, musik, pidato.

4. Writing activities, seperti misalnya menulis cerita, karangan, laporan, angket, menyalin.
5. Drawing activities, misalnya : menggambar, membuat grafik, peta, diagram.

6. Motor activities, yang termasuk di dalamnya antara lain : melakukan percobaan, membuat konstruksi, model mereparasi, bermain, berkebun, berternak.

7. Mental activities, sebagai contoh misalnya : menanggapi, mengingat, memecahkan soal, menganalisis, melihat hubungan, mengambil keputusan.

8. Emotional activities, seperti misalnya, menaruh minat, merasa bosan, gembira, bersemangat, bergairah, berani, tenang, gugup.

Aktivitas belajar siswa disekolah cukup kompleks dan bervariasi. Jika berbagai macam kegiatan tersebut dapat diciptakan di sekolah, maka sekolah akan benar-benar menjadi pusat aktivitas belajar yang maksimal sehingga dapat meningkatkan hasil belajar siswa. Dalam penelitian ini aktivitas yang diamati meliputi Visual activities, Oral activities, Listening activities, Writing activities, Drawing activities, dan Mental activities.

Berdasarkan uraian dari latar belakang di atas rumusan masalah yang akan dikaji dalam penelitian ini yaitu bagaimana cara menerapkan model pembelajaran Problem Posing tipe Pre Solution Posing pada siswa kelas VIII B SMP Negeri 15 Kota Bengkulu agar dapat meningkatkan aktivitas belajar matematika siswa ?

Adapun tujuan penelitian tindakan kelas ini yaitu untuk mengetahui cara menerapkan model pembelajaran Problem Posing tipe Pre Solution Posing pada siswa kelas VIII B SMP Negeri 15 Kota Bengkulu agar dapat meningkatkan aktivitas belajar matematika siswa.

\section{METODE PENELITIAN}

Jenis penelitian yang digunakan dalam penelitian ini adalah Penelitian Tindakan Kelas (PTK). Penelitian tindakan kelas dilakukan secara bersiklus. Menurut Arikunto (2010:137), dalam penelitian tindakan kelas terdapat empat tahapan yang perlu dilakukan, yaitu (1) perencanaan tindakan (planning), 
pelaksanaan tindakan (acting), (3) pengamatan (observing), (4) refleksi (reflecting).

Instrumen yang digunakan dalam penelitian ini adalah lembar observasi aktivitas belajar siswa. Analisis data dalam penelitian ini yaitu data yang bersifat kualitatif berupa informasi berbentuk data observasi aktivitas belajar siswa. Pengisian lembar observasi aktivitas siswa berpedoman pada penskoran seperti yang tertera pada tabel berikut ini:

Tabel 1. Pedoman Penskoran Pengamatan Aktivitas Siswa

\begin{tabular}{|c|c|c|}
\hline $\begin{array}{c}\text { Kriteria } \\
\text { Penilaian }\end{array}$ & Notasi & Skor Nilai \\
\hline Kurang Aktif & K & 1 \\
\hline Cukup Aktif & C & 2 \\
\hline Aktif & B & 3 \\
\hline
\end{tabular}

(Modifikasi Aqib dkk., 2014:67)

Untuk meneliti aktivitas belajar siswa akan diamati oleh dua orang pengamat. Maka analisis rata-rata skor pada hasil observasi aktivitas belajar siswa adalah:

$$
\text { Nilai rata }- \text { rata skor }=\frac{\mathrm{P} 1+\mathrm{P} 2}{2}
$$

Ket : P1 = jumlah skor observasi aktivitas belajar siswa oleh pengamat 1

P2 = jumlah skor observasi aktivitas belajar siswa oleh pengamat 2

Setelah nilai rata-rata skor siswa diperoleh maka kisaran skor penilaian untuk lembar observasi aktivitas belajar siswa adalah :

Tabel 2. Pedoman Kriteria Penilaian

\begin{tabular}{|c|c|}
\hline Kisaran Skor & Kriteria Penilaian \\
\hline $10 \leq x \leq 16$ & Kurang Aktif \\
\hline $16<x \leq 23$ & Cukup Aktif \\
\hline $23<x \leq 30$ & Aktif \\
\hline
\end{tabular}

Ket : $x=$ Skor aktivitas belajar siswa

(Diadaptasi dari Sudjana, 2009:78)

Perhitungan atau analisis per aspek setiap indicator pada lembar observasi aktivitas belajar siswa mengacu kepada pembagian interval yaitu dengan rumus :

$$
\text { interval }=\frac{X_{\max }-X_{\min }}{k}
$$

Sumber : Yunita (2015)
Maka :

$$
i=\frac{3-1}{3}=\frac{2}{3} \approx 0,67
$$

Sehingga didapatkan tabel untuk menganalisis aktivitas per aspek seperti berikut

Tabel 3. Interval Kategori Penilaian Aktivitas Per Aspek yang Diamati

\begin{tabular}{|c|c|}
\hline Interval & Kriteria Penilaian \\
\hline $1 \leq x<1,67$ & Kurang Aktif \\
\hline $1,67 \leq x<2,34$ & Cukup Aktif \\
\hline $2,34 \leq x \leq 3$ & Aktif \\
\hline
\end{tabular}

\section{HASIL DAN PEMBAHASAN}

Penelitian tindakan kelas melalui Penerapan Model Pembelajaran Problem Posing Tipe Pre Solution Posing Untuk Meningkatkan Aktivitas dan Hasil Belajar Matematika Siswa SMP Negeri 15 Kota Bengkulu dilaksanakan dalam 3 siklus. Berdasarkan hasil perhitungan pada lembar pengamatan untuk setiap siklusnya, aktivitas belajar mengalami peningkatan seperti terlihat pada Grafik 1 berikut ini:

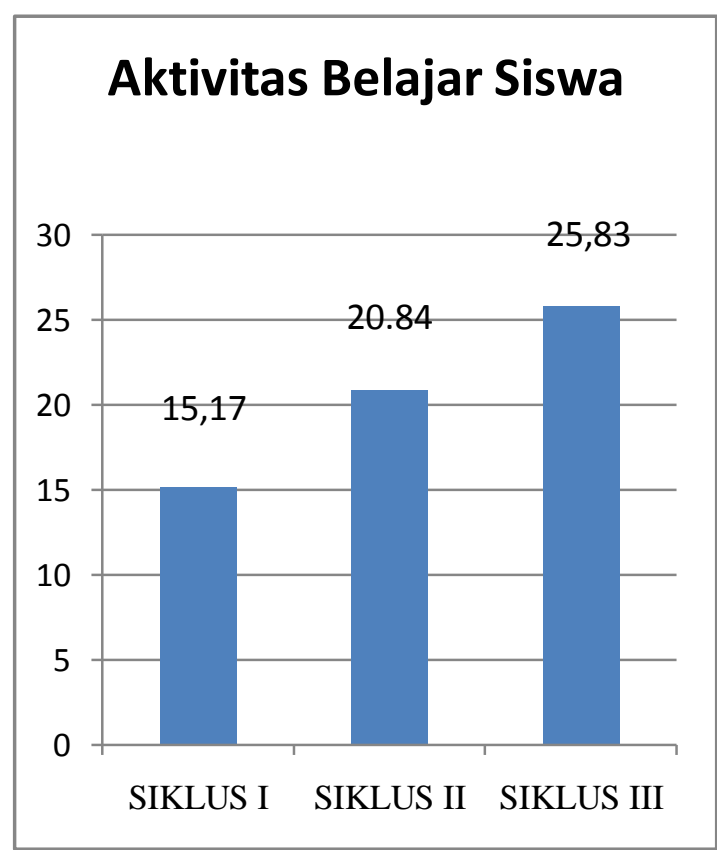

Grafik 1. Peningkatan Aktivitas Belajar Siswa Tiap Siklus

Peningkatan aktivitas ini sejalan dengan peningkatan aktivitas yang dilakukan siswa setiap siklusnya. Peningkatan aktivitas belajar 
siswa dapat dilihat dari penilaian observer untuk setiap aspek pada lembar observasi. Peningkatan aktivitas belajar siswa per aspek setiap siklusnya dapat dilihat grafik 2 berikut.

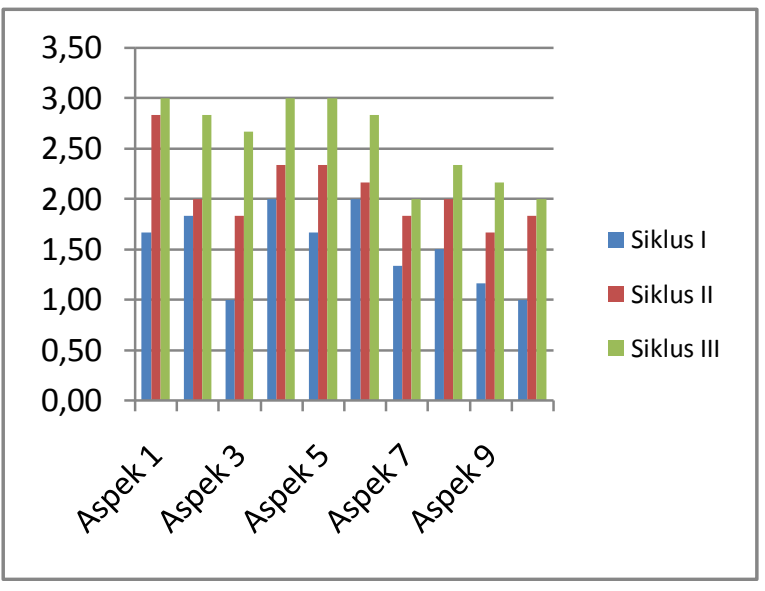

\section{Grafik 2. Peningkatan aktivitas belajar siswa per-aspek pada setiap siklus}

\section{Keterangan :}

Aspek 1: Siswa memperhatikan penjelasan guru tentang hal-hal yang harus diperhatikan dalam membuat soal

Aspek 2: Siswa bertanya mengenai hal-hal yang belum jelas dalam membuat soal

Aspek 3: Siswa antusias dalam membuat soal yang diperintahkan

Aspek 4: Siswa membuat soal secara individu berdasarkan informasi yang tertera pada lembar petunjuk pembuatan soal

Aspek 5: Siswa membuat jawaban berdasarkan soal yang telah dibuatnya

Aspek 6: Siswa menuliskan soal dan jawaban yang telah dibuatnya pada kolom yang telah disediakan pada lembar petunjuk pembuatan soal

Aspek 7: Siswa mempresentasikan soal dan jawaban yang telah dibuatnya di depan kelas

Aspek 8: Siswa memberikan komentar/saran atas soal yang telah dibuat oleh temannya

Aspek 9: Siswa menanggapi komentar temannya mengenai soal yang telah dibuatnya

Aspek 10: Siswa berani mengemukakan pendapat dan menyimpulkan tentang materi yang telah dipelajarinya
Pada siklus I aktivitas belajar siswa masih termasuk dalam kriteria kurang aktif dimana siswa kurang memperhatikan pada saat guru memberikan penjelasan tentang cara membuat soal dan siswa belum berani bertanya tentang hal-hal yang tidak dipahaminya. Hal ini berakibat terhadap soal yang dibuat siswa yang masih termasuk kategori soal belum baik dan terdapat 5 siswa yang tidak membuat soal berdasarkan informasi yaang diberikan. Kemudian menurut hasil dari pengamatan aktivitas dalam melakukan presentasi masih sangatlah kurang. Pada saat presentasi berlangsung ktivitas bertanya, memberikan saran atau komentar dan menanggapi masih sangatlah kurang, hal ini terlihat dari hasil pengamatan bahwa hanya ada 4 orang siswa yang aktif. Oleh karena itu, skor rata-rata aktivitas siswa hanya mencapai kriteria kurang aktif yaitu sebesar 15,17.

Pada siklus II guru memberikan bimbingan dan arahan agar siswa terbiasa untuk membuat soal dan jawaban secara mandiri berdasarkan informasi yang diberikan dan memotivasi siswa untuk bertanya, memberikan saran atau komentar serta menanggapi soal dan jawaban siswa yang melakukan presentasi. Berdasarkan hasil perhitungan pada tabel 3 , terlihat adanya peningkatan aktivitas siswa dengan adanya tindakan yang dilakukan guru, sehingga mencapai kriteria cukup aktif yaitu 20,84. Namun, masih ada siswa yang tidak memperhatikan penjelasan guru tentang hal-hal yang harus diperhatikan dalam membuat soal dan bertanya mengenai hal-hal yang belum dipahaminya sehingga soal yang dibuat siswa masih termasuk kategori soal belum baik.

Tindakan yang dilakukan pada siklus III, mengacu pada hasil refleksi siklus II yaitu guru memberikan motivasi dengan memberitahukan kepada siswa akan ada nilai tambah bagi siswa yang aktif dalam kegiatan presentasi dan nilai yang kurang bagi siswa yang tidak aktif. Hal ini dimaksudkan agar siswa semangat untuk melakukan presentasi dan semakin aktif dalam kegiatan pembelajaran. Tindakan ini terbukti dapat meningkatkan aktivitas belajar siswa sehingga mencapai kriteria aktif yaitu sebesar 25,83 . 
Peningkatan yang terjadi setiap siklusnya, sesuai dengan pendapat Throbroni (2015) yang mengemukakan bahwa keterlibatan siswa untuk turut belajar dengan cara menerapkan model pembelajaran pembelajaran problem posing merupakan salah satu indikator keefektifan belajar. Siswa tidak hanya menerima saja materi dari guru, tetapi juga berusaha menggali dan mengembangkan sendiri. Selain itu pembelajaran problem posing tipe pre solution posing dapat memfasilitasi dan meningkatkan aktivitas siswa. Hal ini dikarenakan dalam pembelajaran dengan menerapkan model problem posing, pada prinsipnya siswalah yang harus aktif mengembangkan pengetahuannya bukan guru atau orang lain. Sehingga dalam kegiatan pembelajaran banyak melibatkan aktivitas siswa untuk membuat soal, melakukan kegiatan presentasi dan menyimpulkan materi yang telah dipelajari.

Peningkatan setiap siklusnya dapat dilihat pada grafik peningkatan aktivitas belajar siswa untuk setiap siklus sebagai berikut:

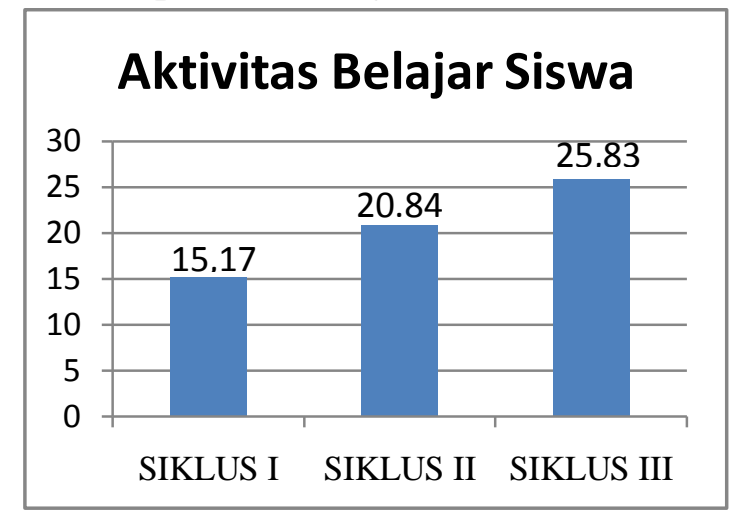

Dalam penelitian ini mempertim-bangkan peningkatan kualitas soal yang dibuat siswa (presentase siswa yang membuat soal dengan kategori soal sudah baik $\geq 70 \%$ ) sebagai salah satu indikator keberhasilan pembelajaran dengan menerapkan model pembelajaran problem posing tipe pre solution posing. Hal ini sesuai dengan Throbroni (2015:288) yang menyatakan bahwa pada prinsipnya model pembelajaran Problem Posing Tipe Pre Solution Posing adalah suatu kegiatan pembentukan soal yang mewajibkan para siswa untuk membuat soal dan jawaban berdasarkan informasi dan situasi yang diberikan oleh guru. Oleh karena itu soal buatan siswa setiap siklusnya harus mengalami perubahan dan semakin baik dari sebelumnya. Soal yang dibuat siswa harus termasuk kategori soal sudah baik. Adapun soal buatan siswa yang termasuk kategori soal sudah baik memenuhi kriteria sebagai berikut : (1) Soal yang dibuat berupa pertanyaan matematika; (2) Soal yang dibuat mempunyai kaitan dengan informasi yang diberikan; (3) Soal yang dibuat dapat diselesaikan; (4) Soal yang dibuat berupa pertanyaan bukan pernyataan; (5) Soal yang dibuat sesuai dengan materi yang sedang dipelajari.

Pada siklus I banyaknya siswa yang membuat soal dengan kategori soal belum baik mencapai $57,29 \%$, sedangkan banyaknya siswa yang membuat soal dengan kategori soal sudah baik hanya mencapai $42,71 \%$. Hal ini menunjukkan bahwa siswa belum terampil dalam membuat soal berdasarkan informasi yang diberikan, ini dikarenakan siswa yang belum terbiasa dengan kegiatan pembelajaran yang menuntut siswa untuk membuat soal dan jawaban secara individu berdasarkan informasi yang diberikan karena selama ini siswa dibiasakan untuk mengerjakan soal-soal yang sudah terdapat pada buku pelajaran, selain itu siswa belum memahami hal-hal yang harus diperhatikan dalam membuat soal agar soal yang dibuatnya termasuk kategori soal sudah baik.

Sedangkan pada siklus II banyaknya siswa yang membuat soal dengan kategori soal sudah baik mengalami peningkatan dari siklus sebelumnya dengan rata-rata presentase yaitu $62,50 \%$, sedangkan banyaknya siswa yang membuat soal dengan kategori soal belum baik mengalami penurunan dari siklus sebelumnya menjadi $37,50 \%$. Hal ini dikarenakan siswa mulai terbiasa untuk membuat soal berdasarkan informasi yang diberikan dan mulai memahami hal-hal yang harus diperhatikan dalam membuat soal sehingga soal yang dibuatnya semakin baik.

Pada siklus III banyaknya siswa yang membuat soal dengan kategori soal sudah baik mencapai $73,95 \%$, hal ini menunjukkan bahwa siswa sudah memahami hal-hal yang harus diperhatikan dalam membuat soal sehingga soal yang dibuatnya semakin baik pada setiap pertemuannya dan banyaknya siswa yang 
membuat soal dengan kategori soal sudah baik telah memenuhi indikator yang ditetapkan sebelumnya yaitu $\geq 70 \%$ siswa sudah membuat soal dengan kategori soal sudah baik. Walaupun masih ada $26,04 \%$ siswa yang membuat soal dengan kategori soal belum baik.

\section{PENUTUP \\ Simpulan}

Penerapan model pembelajaran problem posing tipe pre solution posing di dapat meningkatkan aktivitas belajar siswa dengan cara memberi motivasi kepada siswa untuk aktif dalam kegiatan pembelajaran dan memberi tambahan nilai untuk siswa yang berani mengeluarkan pendapat didepan kelas, baik siswa yang melakukan presentasi atau siswa yang memberi saran maupun komentar, sehingga siswa memiliki motivasi dan keberanian dalam memberikan komentar pada saat kegiatan presentasi. Berdasarkan hasil analisis pada lembar observasi aktivitas belajar siswa terbukti bahwa terjadi peningkatan aktivitas belajar siswa pada siklus I hingga siklus III, secara berturut-turut yaitu: 15,17 (kriteria kurang aktif); 20,84 (kriteria cukup aktif); 25,83 (kriteria aktif).

\section{Saran}

Adapun saran dalam penelitian ini adalah Lembar Petunjuk Pembuatan Soal yang digunakan harus berisi informasi yang tepat sehingga tidak membingungkan siswa ketika membuat soal dan sebaiknya soal yang dibuat siswa bukan hanya pertanyaan saja tetapi soal yang dibuat siswa harus dilengkapi dengan pernyataan dan pertanyaan yang sesuai dengan informasi yang terdapat pada Lembar Petunjuk Pembuatan Soal.

\section{DAFTAR PUSTAKA}

Aqib, Zainal dkk. (2014). Penelitian Tindakan Kelas Untuk Guru SD, SLB, dan TK. Bandung : Yrama Widya.

Arikunto, S. (2010). Prosedur Penelitian Suatu Pendekatan Praktik. Jakarta : Rineka Cipta
Panuntun, Sariayu. (2016). Penerapan Pendekatan Problem Posing Untuk Meningkatkan Kemampuan Pemahaman Konsep Geometri Siswa Di SMP Negeri 4 Kota Bengkulu. Bengkulu. Skripsi : Universitas Bengkulu

Sardiman. (2011). Interaksi dan Motivasi Belajar Mengajar. Jakarta : Rajawali Pers.

Shoimin, A. (2016). 68 Model Pembelajaran Innovatif dalam Kurikulum 2013. Yogyakarta : Ar-Ruzz Media

Sudjana, Nana. (2009). Penilaian Hasil Proses Belajar Mengajar. Bandung : Remaja Rosdakarya.

Suryosubroto. (2009). Proses Belajar Mengajar di Sekolah Wawasan Baru, Beberapa Metode Pendukung, dan Beberapa Komponen Layanan Khusus. Jakarta : Rineka Cipta.

Throbroni. (2015). Belajar dan Pembelajaran Teori dan Praktik. Yogyakarta : ArRuzz Media 